\title{
Investigation of Work Accidents in Vocational and Technical High Schools
}

\author{
Ahmet Yurtçu \\ Work Safety and Health Programme, İstanbul Gedik University, Turkey
}

Copyright $\subseteq 2019$ by authors, all rights reserved. Authors agree that this article remains permanently open access under the terms of the Creative Commons Attribution License 4.0 International License

\begin{abstract}
As indicated in work accident reports in educational contexts, it can be noted that students in vocational and technical high schools involved in work accidents are often inexperienced individuals in the tasks or don't have enough occupational knowledge. In this regard, it wouldn't be wrong to say that a thorough occupational health and safety (OHS) awareness must be raised and students must be provided with proper work health and safety education. This study dwells on reported occupational accident cases taking place in Vocational and Technical Anatolian High Schools affiliated with Ministry of National Education (MoNE) in Amasya, Kırşehir and Aydın provinces in Turkey. A total of 147 teachers were solicited for the study in 20 schools. Purposeful and criteria sampling methods were employed while selecting the participants. A qualitative research method was adopted in this study. Data were obtained through semi-structured interview form and obtained data were analysed through content analysis technique. Because of the statistical analysis of the data obtained, the factors affecting the work accidents are presented and the suggestions are given for the precautions to be taken to prevent work accidents or to reduce them to minimum levels.
\end{abstract}

Keywords Occupational Health and Safety (OHS), Vocational and Technical Education, Work Accidents

\section{Introduction}

Work accidents may take place due to several unexpected factors, which lead to damage and claim lives. Design, setting or operation errors, which cause accidents in workplaces are noticed only if workers launch a task and encounter several risks. Work accidents and occupational ailments mostly stem from system problems, design errors, inconvenient and neglected equipment and machines, human related factors, lack of education and supervision [26]. Occupational safety is conceptualized as determination of safety precautions and their implementation scientifically to minimize the work accidents causing some losses [9]. The most fundamental objectives of occupational health and safety (OHS) principles and standarts are to form a healthy work environment for individuals. To realize this aspiration, proper education must be a priority so that a safe and health work environment can be achieved [2]. Occupational safety aims to protect workers as well as their organizations and productions against dangers and harms. At this precise point, it has been reported that health and safety of individuals must be paid attention before that of organisation, productions or equipment since human life is of great importance in both national and international legislations and standarts [9].

When we examine OHS in Turkey, it can be seen that it ranks at the front lines internationally in terms of work accidents [15]. On the other hand, a systematic review of literature has revealed that very few scholars have focused on OHS issues in Turkey when compared to international literature. Individuals spend a great deal of time in their workplaces, so they are subjected to risks more than somewhere else [22]. Individuals who have experienced work accidents may lose their workforce partly or completely. Workers sometimes become dependent on others although they were productive workforce before a workplace accident. Said another way, work accidents or occupational ailments mainly make individuals themselves victims. Additionally, those who need the subsistence of workers, namely families of workers, also suffer from the results [19]. Individuals who cannot work after a work accident are paid two thirds of their regular salary in accordance with Social Safety Institution (SSI) legislations in Turkey [23]. If the worker doesn't have a social security, there happens worse results. Given that $40 \%$ individuals work without a legal social security in workplaces, it wouldn't be difficult to mention that those individuals without a social security will suffer more than those who have social security [28].

In workplaces, providing a safe working environment for workers is inevitable not only for humanistic sensations, but for financial costs, as well. Expenses on occupational 
and health issues enable employees to reduce risks as well as manufacturing costs. At the beginning, it may seem that OHS implementations bring a heavy burden for companies, but it can be suggested that they will contribute both financially and effective workforce in the long term [5].

Governments are responsible for prevention of work accidents as well as their citizens' well-being and welfare. A systematic supervision and planning business relations to diminish problems and are also entitled as their responsibilities. On the other hand, it can be asserted that legislations and regulations in Turkey don't satisfy expectations of all stakeholders in terms of OHS. It has well been known that there have been enough OHS experts in Turkey. However, the problems arise while conducting existing implementations. $10 \%$ of workplaces can be supervised although it is expected that effectiveness must be improved [8]. Correspondingly, it can be noted that inclusion of OHS issues in educational systems must be a lifelong learning objective for countries. In other words, there must a continuous education process from kindergarden to retirement periods of individuals. For this purpose, the basic concepts of health and safety must be provided for children and adolescents while instructing them on dangers and risks in the life itself. These achievements can be obtained in schools and other educational contexts as health and safety culture. Integration of OHS into education, namely curriculum, can be easily exercised thanks to interdisciplinary studies of OHS and educational sciences.

OHS can be considered as a cultural issue. This consciousness and awareness in societies cannot be realized in shorter period of time. Rather, a social understanding of an issue needs longer periods of time to settle in any society since societies compromise of huge populations. When we examine the statistics on work accidents in Turkey, it can be clearly seen that most of the work accidents result from human-related factors. One of the primary causes of these can be listed as: ignoring the rules of OHS, not using personal protective equipment or using it improperly [23]. There is evidence corroborates this and mentions that insufficient awareness on OHS and improper use of sophisticated machines in workplaces are common causes of work accidents. In this regard, this situation can be attributed to deprivation of a culture on OHS and proper education on the issue. Acquiring the necessary knowledge and adopting a culture on OHS take longer periods [29].

The fact that students in vocational and technical high schools educating service staff for working life give importance to OHS issues thanks to education will undoubtedly help them to have a culture on the issue. At this precise point, it can be argued that OHS has a special importance in vocational and technical educational institutions. This is due to the fact that young students encounter vocational and technical issues for the first time in these schools. It is fundamental to create awareness and gain consciousness on OHS. In line with this, it was concluded that forming a culture on OHS is precedence for abstaining from dangers in workplaces and making individuals become aware of risks [18]. On the other hand, It was emphasized that OHS culture is not a phenomenon between employer and employee, but is an issue which must be paid attention by all stakeholders and must be included in curriculums in educational settings [21].

When the data provided by Turkish Statistical Institute (TSI) on work accidents and occupational ailments in Technical and Vocational High Schools in 2016 is examined, it can be seen that a total of 2437 people, 960 of whom were men, had work accidents. 2242 people were reported as serviceable, while 12 individuals couldn't produce any service. 183 people were entitled two and more health reports, which mention that they cannot work during this period [25]. This situation indicates the status of OHS in vocational and technical schools. Based on the statistical data and lack of abundant research on the issue, this study is to investigate work accidents in vocational and technical schools and to provide a baseline for research and practice on OHS. Additionally, this study is to contribute to the field of OHS through the findings of the work accidents that have occurred in vocational and technical high schools. This study is to fill the void on OHS in terms of educational contexts.

\subsection{Purpose of the Research}

Education on OHS is conducted as a subdiscipline of some courses in educational organizations affiliated with Ministry of National Education (MoNE). These results are insufficient knowledge and experience on OHS. It was stated that lack of education on OHS would end up with work accidents [4]. Based on an extensive literature review, it can be noted that work accidents taking place in private organizations have generally become the focus of scholars $[11 ; 20 ; 26]$. In this regard, the main goal of the current study was to investigate the work accidents experienced in vocational and technical educational contexts and to fill this void by providing some compelling evidence. In this investigation, the causes and results of work accidents were attempted to examine and to provide some theoretical and practical implications. This study sets out to reveal the perceptions of teachers working in vocational and technical schools. In line with this purpose, the research questions listed below framed the study:

1. What are the perceptions of teachers towards work accidents' causes and results?

2. What are the perceptions of teachers towards the prevention or alleviation of work accidents in vocational and technical schools?

\section{Materials and Methods}

\subsection{Research Model}

This study focusing on work accidents in different 
departments of vocational and technical high schools was designed as a qualitative research. Qualitative studies encompass investigation of events or phenomena in their natural contexts through some qualitative data collection methods, including observation, interviews, and document analysis [27].

\subsection{Participants}

A total of 147 participants from Amasya, Kırşehir and Aydın provinces in Turkey were solicited for this study. The data were collected in 20 vocational and technical high schools affiliated with MoNE. Purposeful and criteria sampling methods were used in this study. Purposive sampling can have many variants, and each variant rests on a different purpose for selecting the participants. In this sense, the nature of the study may require specific criterias, such as selecting extreme or deviant cases, or cases which meet several predetermined criteria [30]. The criteria employed while determining the participants was that the research site schools must be vocational and technical high schools affiliated with MoNE so that the information on the work accidents can be obtained directly from the data sources. Said another way, the vocational and technical teachers are the primary data sources as they have experienced or witnessed the accidents in their classrooms. In line with this aim, demographic information on the participants can be seen in Table 1 .

As shown in Table 1, most of the participants were male teachers $(75.5 \%)$. The participants were often between 31-50 age range and mostly had 11-30 years of working experiences. When it comes to distribution of the participants in terms of teaching branch, it can be seen that electric-electronic department, metal technology, ICT technology include more participants when compared to others.

Table 1. Demographic Information

\begin{tabular}{|c|c|c|c|c|c|}
\hline \multirow{2}{*}{ Gender } & Female & 36 & \multirow{14}{*}{ Branch } & Electric-Electronic Technology Department & 28 \\
\hline & Male & 111 & & Metal Technology Department & 22 \\
\hline \multirow{5}{*}{ Age } & & & & ICT Technology Department & 19 \\
\hline & $20-30$ & 11 & & Machine Technology Department & 13 \\
\hline & $31-40$ & 50 & & Furniture and Interior Design Department & 12 \\
\hline & $41-50$ & 60 & & Other & 8 \\
\hline & 51 and above & 26 & & Health Services & 6 \\
\hline \multirow{7}{*}{$\begin{array}{c}\text { Work } \\
\text { Experience }\end{array}$} & & & & Motor Vehicles Technology Department & 6 \\
\hline & 10 and less & 28 & & Accounting and Finance Department & 6 \\
\hline & $11-20$ & 54 & & Pre-primary Department & 6 \\
\hline & $21-30$ & 55 & & Clothing Manufacturing Department & 6 \\
\hline & 31 and above & 10 & & Hand Crafts Department & 5 \\
\hline & & & & Food and Drink Services & 4 \\
\hline & Total & 147 & & Total & 147 \\
\hline
\end{tabular}




\subsection{Data Collection}

A semi-structured interview form was designed to collect data on work accidents, which participants had experienced or witnessed. The form had two parts: demographic information and research questions. Before the interviews, the semi-structured form had been designed based on the literature and two field experts had provided feedback. According to opinions of field experts, the final version of the form was designed, and three teachers were asked to reply questions. During this first implementation, the suitability and understandability of the form were checked. Interviews were held both in person and via online methods when it was difficult to reach the participants for a variety of reasons such as busy program, or long distances.

\subsection{Data Analysis}

In this study, the analysis of the qualitative data obtained from the participants move through five phases, compiling, disassembling, arraying, interpreting, and concluding [30]. Content analysis technique was employed to analyse the collected data. Content analysis technique is defined as evaluating and classifying the data in a systematic way according to some certain steps, such as coding, and recoding [6]. Before the analysis, all the data were revised and classified according to the types of work accidents. Afterwards, the data were coded and recoded to summarise them in accordance with the types of work accidents. While analyzing the data, the frequency of the words related to work accidents was considered as significant part of the content analysis [30]. While conducting coding process, the data were categorised according to some subthemes, such as types of the work accident, how it took place, where it happened, which department it occurred, time of the work accident, the main reason, results and practices after work accidents. When the data were classified into categories, another field expert was asked to revise the data and form codes. A field expert was also made to create conceptual categories. The resulting themes, categories and codes are calculated [17]. According to Miles and Huberman' formulate [17], reliability $=$ opinion union / opinion union + opinion separation formula, the agreement between the researcher and the expert must be over $90 \%$.

\section{Findings}

\subsection{Findings on Work Accidents in Vocational and Technical Schools}

When the data were analysed, the findings are presented in Table 2 through several categories, including, 'type of the accident', 'the department where the accident took place', 'the time of the accident', 'the causes of the accident', ' the results of the accident', ' the grade level of the sufferer', 'which lesson it occurred', 'practices after the accident'. Based on the results, it can be said that the accidents caused by injury from machine or equipment are the most common types in terms of the type of the accident in vocational and technical high schools. Additionally, it was found that $10^{\text {th }}$ grade students are more subjected to work accidents when compared with others and the accidents often take place in the early times of the day. The causes of the accidents are often human-related factors and fortunately, they often end up with no injury. On the other hand, the accidents typically take place in ateliers or laboratories while practicing and proper first aid is made to the victims. 
Table 2. Information on Work Accidents in Vocational and Technical High Schools

\begin{tabular}{|c|c|c|c|c|c|}
\hline & & f & & & $\mathbf{f}$ \\
\hline \multirow{9}{*}{$\begin{array}{l}\text { Type of the } \\
\text { Accident }\end{array}$} & Injured by machine or equipment & 35 & \multirow{9}{*}{ Grade Level } & & \\
\hline & Electrical shock & 24 & & $10^{\text {th }}$ grade & 63 \\
\hline & Limb cuts & 23 & & $11^{\text {th }}$ grade & 50 \\
\hline & Falling object & 21 & & $12^{\text {th }}$ grade & 23 \\
\hline & Other & 17 & & Child & 5 \\
\hline & Burnt & 11 & & General classrooms & 3 \\
\hline & Falling from a high point & 7 & & Teacher & 2 \\
\hline & Biological factors & 6 & & Administrator & 1 \\
\hline & Poisoning & 3 & & & \\
\hline & Total & 147 & & Total & 147 \\
\hline \multirow{26}{*}{ Department } & Electric-Electronic Atelier & 23 & \multirow{44}{*}{$\begin{array}{l}\text { after the } \\
\text { accident }\end{array}$} & Regular Atelier Practices & 35 \\
\hline & Metal Technology Atelier & 18 & & Outside classroom & 16 \\
\hline & ICT Atelier & 16 & & Electric-Elektronic Measurement & 14 \\
\hline & Furniture Atelier & 12 & & Training Period in Firms & 14 \\
\hline & School Building & 10 & & The foundations of ICT & 6 \\
\hline & Machine Technology Atelier & 9 & & Machine Atelier Practices & 5 \\
\hline & Hospital & 8 & & Arc Weld Techniques & 5 \\
\hline & Motor Vehicles Technology Atelier & 6 & & Technical Services & 4 \\
\hline & School Garden & 5 & & Stitch & 4 \\
\hline & Classroom & 5 & & Automatic Controlling Systems & 3 \\
\hline & Clothing Atelier & 5 & & Furniture Design Techniques & 3 \\
\hline & Weld Atelier & 4 & & Basic Production Operations & 3 \\
\hline & Kitchen & 4 & & Basic Metal Design & 3 \\
\hline & Hand Crafts Technology Atelier & 4 & & Food and Drink & 3 \\
\hline & Building Site & 2 & & Computer Visual Programming & 2 \\
\hline & Printed Circuit Atelier & 2 & & Embroidery Atelier & 2 \\
\hline & Operating Atelier & 2 & & Electric Machines & 2 \\
\hline & Corridors of Atelier & 2 & & Computer Package Programmes & 2 \\
\hline & Moulding Atelier & 2 & & Hair Design & 2 \\
\hline & Beauty and Hair Care Services Atelier & 2 & & Moulding Course & 1 \\
\hline & Furniture Warehouse Atelier & 2 & & Winding & 1 \\
\hline & School Dining Hall & 1 & & Extrusion Moulding & 1 \\
\hline & Industrial Area & 1 & & Open Source Operating System & 1 \\
\hline & Health Services Laboratory & 1 & & Public Health & 1 \\
\hline & Metal Technology Warehouse & 1 & & Furniture Construction Knowledge & 1 \\
\hline & Total & 147 & & Board Guard & 1 \\
\hline \multirow{3}{*}{ Time } & Morning & 113 & & Lathe Techniques & 1 \\
\hline & Afternoon & 34 & & Interior Furniture Design & 1 \\
\hline & Total & 147 & & Natural Gases Plumbing & 1 \\
\hline \multirow{5}{*}{ Cause } & Human Mistake & 125 & & Heating Systems & 1 \\
\hline & Working Environment & 22 & & Weaving Rug & 1 \\
\hline & Machine-Equipment & 13 & & Oxidase Source & 1 \\
\hline & Unhindered Causes & 1 & & Production Methods & 1 \\
\hline & Total & 161 & & Cold Forming & 1 \\
\hline \multirow{10}{*}{ Result } & Mild Injury & 89 & & Plastering & 1 \\
\hline & Outpatient Treatment & 47 & & Basic Dough Techniques & 1 \\
\hline & Loss of Work Force & 21 & & Basic Vocational Practises & 1 \\
\hline & Damage to Machines and Equipment & 12 & & Panel Design and Montage & 1 \\
\hline & Stop Production and Services & 6 & & Total & 147 \\
\hline & Severe Injury & 5 & & First Aid & 101 \\
\hline & Damage to Work Place & 4 & & Informing Authorities & 49 \\
\hline & Limb Loses & 3 & & Medical Support & 47 \\
\hline & Death & 1 & & Official Work Accident Report & 36 \\
\hline & Total & 188 & & Total & 233 \\
\hline
\end{tabular}




\subsection{Findings on Prevention of Work Accidents in Vocational and Technical High Schools}

Table 3. Precautions for Work Accidents

\begin{tabular}{lll}
\hline Theme & Codes & f \\
& Regular maintenance and equipment control & 13 \\
& Using machine and equipment protective & 10 \\
Engineering Precautions & Building guardrail & 2 \\
& Raising walls & 1 \\
\hline \multirow{3}{*}{ Administrative Precautions } & OHS education & 23 \\
& Warning Signboards & 7 \\
& Working under supervision of teacher & 5 \\
& Regulating working time & 3 \\
& Being careful & 55 \\
& Obeying the rules & 31 \\
& Using Personal Protective Equipment (PPE) & 15 \\
& Anger Management & 2 \\
& Being serious while working & 1 \\
\hline Prsonal Precautions & Proper storage & 13 \\
& Using right equipment for right work & 5 \\
& Tidying up workplace & 5 \\
\hline & Total & 3 \\
\hline
\end{tabular}

As shown in Table 3, the findings are categorised based on the classification in the literature and regulations on OHS. In this sense, 'Engineering Precautions', 'Administrative Precautions', 'Personal Precautions' and 'Work Hygiene' are the categories. When the engineering precautions theme is examined, it is seen that regular maintenance and equipment control $(n=13)$, using machine and equipment protective $(n=10)$, building guardrail $(n=2)$ and raising walls $(n=1)$ are the codes in this section. Some of the examples of the participants' views are as follows:

"More advanced electronic protection systems can be used using today's technology. " P37

"Color icons should be placed on the equipment and sensors should be added to ensure that these equipment will not operate when they are installed on the machine." P42

When the administrative precautions theme is examined, it is seen that OHS education $(\mathrm{n}=23)$, warning signboards $(\mathrm{n}=7)$, working under supervision of teacher $(\mathrm{n}=5)$, and regulating working time $(\mathrm{n}=3)$ are the codes in this section. Some of the examples of the participants' views are as follows:

"The accidents that occurred could have been prevented by stimulating the students in different courses on occupational accidents and raising awareness on occupational accidents. " P81

"Machine usage specifications and occupational safety could have been repeated more frequently to prevent the student and the employee to comply with the rules." P88

"The students could have been told more about the dangers related to the machines, and the instructions on safe handling of the machine could have been taken further." P118

"In order to ensure careful study, stimulant information can often be provided, and only a long and tiring work can be done to increase concentration." P140

When the personal precautions are examined, it is seen that being careful $(n=55)$, obeying the rules $(n=31)$, using personal protective equipment (PPE) $(n=15)$, anger management $(n=2)$ and being serious while working $(n=1)$ are the codes in this section. Some of the examples of the participants' views are as follows:

"It was certainly an accident that occurred as a result of carelessness and ignorance. However, attention should have been paid to the selection of working hours on such machines. " P137

"For the machinery and equipment to be tested, it was necessary to provide safe usage conditions and personal protective equipment." $P 28$

"It could be prevented by using the PPE which were given to the security of the company to ensure the security of the business. Even if it happened, the fall could not have resulted in death. " P28

When the personal precautions are examined, it is seen that proper storage $(n=13)$, using right equipment for right work $(n=5)$, and tidying up workplace $(n=3)$ are the 
codes in this section. Some of the examples of the participants' views are as follows:

"When stacking the material, it should be arranged as less upgrades and the area should not be constricted in a wide area. " P84

"The appropriate work clothing should have been used in the working environment." P40

When the proposed precautions in Table 3 are examined, it can be seen that the most repeated code is included in Personal Precautions theme. Similarly, regular maintanenca and equipment control is another most repeated code in engineering precautions theme. OHS education is the most repeated code in administrative precaution theme, while proper storage was mentioned more than others in work hygiene theme.

\section{Discussion and Conclusions}

This study has sought to investigate the work accidents taking place in vocational and technical high schools. The findings clearly indicate that the types of the work accidents are often machine and equipment injuries, electric shocking, limb cuts, falling objects and burnt. These findings align with that of Chamber of Mechanical Engineers Occupational Health and Safety report [10], which has documented that the sectors where work accidents often happen can be listed as: metal production, building, food and drink services. Additionally, there is evidence that falling from high points, biological factors, poisoning are among the findings.

Emerging evidence suggests that several ateliers, such as electric-electronic, metal technology, ICT technologies, furniture design and school buildings are common locations where work accidents take place. This substantiates previous findings in the literature. Gumus [2] for example, concluded that work accidents mostly happen in such places as industrial areas, building sites, open mining areas, public buildings, office and entertaining centers. Additionally, in this present study, all the evidence pointed to the conclusion that early periods of the day are the time when work accidents occur. This finding concurs well with Ocal and Çiçek [18] who concluded that work accidents mostly took place between 11:00-11:59 in 2017. This evidence makes us to suggest that individuals could be more absent-minded or thoughtful during early periods of the day, so they may not attach the utmost importance to OHS principles.

When we dwell on the basic causes of work accidents, it is seen that most of them stem from human mistakes or negligence of safety precautions. Additionally, working environments and such equipment as machines are the causes of work accidents. Compelling evidence indicates that unhindered causes don't play an important role in work accidents. Rather, most of the causes are considered as preventable ones, so individuals could have avoided most of the accidents if they had paid attention to the principles of OHS. As identified in the report by Chamber of Mechanical Engineers Occupational Health and Safety report [10], the core causes of work accidents are risky human behaviors and ignorance of basic safety issues as well as machines and equipment in workplaces. Additionally, ILO statistics [13]. are in good agreement with findings of this study. It has been reported by ILO [13] report that $88 \%$ of work accidents occur due to negligence of individuals, while $10 \%$ are caused by insecure working conditions and unhindered factors account for $2 \%$.

The findings clearly show that work accidents result in mild injuries, outpatient treatments and injuries which prevent individuals from servicing. Additionally, damage to machines and equipment, stopping production and services, severe injuries, damage to workplace, limb losses and death are also revealed in the voices of the participants. Uysal, Ozciftci and Kurt [26] are in line with this and conclude that most of the work accidents result in mild or severe injuries and loss of work force.

Further analysis revealed that 10th and 11th grade students in vocational and technical school are often subjected to work accidents since they are inexperienced in terms of the related occupation and its machines or equipment. It was found that there is a clear reduction in the statistics of work accidents including 12th grade students (more than 50\%). This can attributed to their increased knowledge and awareness both related occupation and principles of OHS. In this regard, it would be better to suggest that the freshman students must be provided a detailed education on OHS and paid more attention in terms of risks and dangers in workplaces. It was concluded that new beginners in a workplace are exposed to work accidents more than experienced individuals, as well [7].

When it comes to the courses in which work accidents occur, it was found that regular atelier practices, out of classroom and training periods in firms are common moments of work accidents. These findings mean that work accidents occur during regular atelier practices more than other courses included in MoNE curriculum. Jacobsson, Jensen and Jansson [14] concluded that accidents in schools happen during breaktimes and physical education lessons. Correspondingly, it can be noted that teachers need to care students during courses. Otherwise, students may experience accidents. Additionally, a continuous warning must be presented to the students. Safety at workplaces must be a priority for all individuals in vocational and technical high schools.

Participants' voices revealed that the first interventions are often first aid and informing authorities in the event of work accident. Providing medical support and preparing official work accident report are another practices when a work accident is encountered. It was also revealed that authorities aren't sometimes informed, or official work accident reports aren't prepared when there is a small 
accident without any harm. These results in insufficient statistical data related to work accidents in educational institutions. This is a striking finding of the study in that those small accidents could have resulted in worse conditions. In other words, the fact that there isn't any damage doesn't necessarily mean this couldn't have taken place in workplaces. It is therefore important that individuals in vocational and technical educational contexts must be aware that accidents are very fundamental for the prevention of future risks and dangers. Akilli and Aydogdu [1] concur well with this and mention that a detailed accident report must be prepared in case of an accident in workplaces. On the other hand, it is an obligation according to legal regulations made by Work Health and Safety Legislation with the reference 6331 [23].

When it comes to precautions for work accidents, there is evidence to suggest that engineering, administrative and personal precautions as well as work hygiene are four themes formed after the analysis. Within this context, participants strongly offered that regular controls and maintanenca of machines and equipment must be conducted to reduce the risks. Additionally, building guardrails and raising walls are other precautions suggested by the participants. OHS education was included in the analysis under the administrative precautions theme. Warning signboards, working under control of teachers and regulating working times are other findings. Several scholars are in good agreement with this [3;21]. It has been reported that OHS education plays a significant role in prevention of work accidents. Another result to emerge from the data is that being careful, work cautiously and obeying the rules are personel precautions in the prevention of work accidents. PPE usage is another means of protection. With regard to this, it was concluded that being distracted, lack of experience, improper equipment, negligence, machines without proper maintenance and not taking the work seriously are the primary causes of work accidents [26].

The results have suggested that there is still a huge gap that needs to be filled in OHS education in vocational and technical high schools. Previous research has shown that the awareness about work accidents aren't at satisfactory levels in Turkey. At this precise point, it wouldn't be wrong to say that the findings of this study may be important for home accidents as much as workplaces. Said another way, the consciousness on OHS should be formed in the houses, as well. The awareness on work accidents can be a workplace culture, so all stakeholders must take the burden of raising this awareness in vocational and technical high schools.

\section{Limitations}

There are some limitations, which must be issued although the results of this study offer useful evidence. First of all, this study draws on data in a few cities in
Turkey. It can be proposed that further research should be undertaken in different schools, especially in higher education vocational and technical schools so that it would be possible to draw more conclusive evidence on work accidents. Further research is also needed to conduct on private companies. Thus, there may be some useful comparisons between public and private institutions. Secondly, as it can be seen from the findings, the work accidents reported in this study mostly took place in electric-electronic, metal and furniture departments. This is due to the fact that more participants agreed on to take part in the study. It would also be useful to conduct a longitudinal research design to address the causes and results of work accidents in workplaces.

\section{Recommendations}

Based on findings revealed in the study, there are some recommendations for all stakeholders in OHS field.

For practitioners: Students must be controlled while conducting their works to reduce or eliminate the risks of work accidents. A detailed information on the task to be done, on the machine to be employed and on the equipment to be used to make use of them in an effective way. Psychological well-being of the students must be observed before assigning a task for them. Time planning must be made according to curriculum and the vocational and technical courses must be placed in proper times, when students are in alert positions rather than very early or late periods of the day.

For researchers: It would be advisable to conduct studies recruiting more participants in quantitative and qualitative nature. Cross-national analysis would be better to take a full picture of the issue.

For policy makers: OHS Education must be placed as a separate course in curriculums of vocational and technical schools at all levels. Legal regulations must be included in OHS Education so that students grasp the legal status and importance of OHS.

\section{Coda}

In summation, the findings of this study broad the current knowledge on work accidents in terms of OHS, revealing practical implications as well as future research avenues. In this regard, it can be noted that OHS education and awareness aren't at expected levels. When MEGEP modules that are included in OHS education provided by MoNE Vocational and Technical Education General Directorate are examined, it is seen that OHS education is included as a small part in curriculum [16]. It would be better to include OHS education as a separate discipline in curriculums. In line with this, OHS education must be included in all grade levels in education systems since accidents occur not only in our workplaces but in our 
houses, as well. Therefore, it can be noted that OHS is significant for all.

\section{Acknowledgements}

We are very grateful to experts for their appropriate and constructive suggestions to improve this template.

\section{REFERENCES}

[1] Akilli, H. \& Aydogdu O. (2016). Maden Tetkik ve Arama Genel Müdürlüğü Enerji Hammadde Etüt ve Arama Dairesi Başkanlığı. Ankara: İş Sağlığı Ve Güvenliğinin Önemi.

[2] Alli, B. O. (2008). Fundamental principles of occupational health and safety Second edition. International Labour Office, Geneva.

[3] Aydin, U., Karaca, N., Ozguler, V., \& Karaca, E. (2013). İş sağlığı ve güvenliği eğitiminin iş kazaları ve meslek hastalıklarının önlenmesindeki rolü. Çimento endüstrisi işverenleri sendikası, 27(4), 28-29.

[4] Benamghar, L., Chau, N., Saunier-Aptel, E., Mergel, B., \& Mur, J. M. (1998). Accidents among students in professional or technological schools in Lorraine. Revue d'epidemiologie et de sante publique, 46(1), 5-13.

[5] Bozkurt, R. (1993). Application of modern accident prevention techniques to OAL mines (TKI). Master Thesis, METU, Ankara.

[6] Buyukozturk, S., Cakmak, E. K., Akgun, Ö. E., Karadeniz, S., \& Demirel, F. (2017). Bilimsel araştırma yöntemleri. Ankara: Pegem.

[7] Camkurt, M. Z. (2013). Çalışanların kişisel özelliklerinin iş kazalarının meydana gelmesi üzerindeki etkisi. TÜHİS İş Hukuku ve İktisat Dergisi, 26(6), 1-2.

[8] Centel, T. (2000) İşçi sağlığı ve iş güvenliği mevzuatı. İstanbul: MESS.

[9] Ceylan, H. (2012). Türkiye'deki iş sağlığı ve güvenliği eğitimi sorunlar ve çözüm önerileri. Ejovoc (Electronic Journal of Vocational Colleges), 2(2), 94-104.

[10] Chamber of Mechanical Engineers (2013). Chamber of Mechanical Engineers, 2013. Final Report of VII. National Occupational Health and Safety Convention, April 2013. $<$ http://www.mmo.org.tr/etkinlikler/isag/etkinlik_metin.ph p? etkinlikkod=260\&metin_kod=1072> (accessed 12.01.15) (in Turkish).

[11] Ercan, A. (2010). Türkiye'de yapı sektöründe işçi sağlığ1 ve güvenliğinin değerlendirilmesi. Politeknik Dergisi, 13(1), 49-53.

[12] Gumus, R. (2017). Türkiye'de 2015 yılında meydana gelen iş kazalarının analizi ve 2014 yılı verileri ile karşılaştırılması. The Journal of Academic Social Science Studies, (55), 277-287.doi: /10.9761/JASSS6916

[13] ILO (2018). https://www.ilo.org/global/statistics-and-datab ases/lang--en/index.htm

[14] Jacobsson, B., Bek-Jensen, H., \& Jansson, B. (1986). One year's incidence of school accidents and their severity in a Swedish municipality. Scandinavian journal of primary health care, 4(4), 213-217.

[15] Karadeniz, O. (2012). Dünya'da ve Türkiye'de iş kazaları ve meslek hastalıkları ve sosyal koruma yetersizliği. Calisma ve Toplum, 34(3).

[16] MEGEP (2018). http://www.megep.meb.gov.tr/ Accessed on 25.02.2019.

[17] Miles, M. B., \& Huberman, A. M. (1994). Qualitative data analysis. 2. Aufl., Thousand Oaks et al.

[18] Ocal, M., \& Cicek, O. (2017). Türkiye ve Avrupa Birliği'nde iş kazası verilerinin karșılaştırmalı analizi. Hak İs Uluslararası Emek ve Toplum Dergisi, 6(16), 616-637.

[19] Odaman, S. (2005). 4857 sayılı yeni iş kanunu döneminde iş sağlığı ve güvenliği hükümlerinin önemi ve OHSAS 18001 Yönetim Sistemi. MERCEK Dergisi, 10(39), 132.

[20] Ozkan, O., \& Emiroglu, O. N. (2006). Hastane sağlık çalışanlarına yönelik işçi sağlığı ve iş güvenliği hizmetleri. Hemşirelik Yüksekokulu Dergisi., 10(3), 43-51.

[21] Schulte, P. A., Stephenson, C. M., Okun, A. H., Palassis, J., \& Biddle, E. (2005). Integrating occupational safety and health information into vocational and technical education and other workforce preparation programs. American Journal of Public Health, 95(3), 404-411.

[22] Tanir, F. (2004). İş sağlığ1 ve güvenliği. İş Sağlığ 1 ve Güvenliği Genel Müdürlüğü, İş Sağllğ̣ ve Güvenliği Dergisi, (17).

[23] The Official Gazette (2012).http://www.resmigazete.gov.tr/ eskiler/2012/06/20120630-1.htm. Accessed on 25.02.2019.

[24] The Official Gazette (2018).http://www.resmigazete.gov.tr/ eskiler/2018/05/20180521-1.htm Accessed on 25.02.2019

[25] TSI, (2013). Turkish Statistical Institute, 2015. Genel sanayi ve işyeri sayımı-2002. < http://www.tuik.gov.tr/VeriBilgi.d o?alt_id $=1079>($ accessed 15.01.19).

[26] Uysal, B. Ozciftci, A. Kurt, Ş. (2005). Türkiye'de küçük ve orta ölçekli mobilya imalat işletmelerinde meydana gelen is kazalarının analizi, G.Ü. Fen Bilimleri Dergisi, 18(3): 439-451.

[27] Yildirim, A. \& Simsek, H. (2013). Sosyal bilimlerde nitel araştırma yöntemleri. (9. baskı). Ankara: Seçkin Yayıncılık.

[28] Yilmaz, F. (2009). İş Sağlığı ve Güvenliği’nde Okul Eğitiminin Önemi Modern Örnekler Işığında İş Sağlığı ve Güvenliği Lisans Eğitiminin Ülkemizde Uygulanabilirliği. İş Hukuku ve İktisat Dergisi, 11, 107-139.

[29] Yilmaz, H. (2013). İş kazası kavramı ve sonuçları, (Yayınlanmış Yüksek Lisans Tezi). Marmara Üniversitesi, Sosyal Bilimler Enstitüsü, İstanbul.

[30] Yin, R. K. (2015). Qualitative research from start to finish. Guilford Publications. 